\section{EFEKTIVITAS TERAPI RENDAM KAKI AIR HANGAT DAN RELAKSASI NAFAS DALAM TERHADAP TEKANAN DARAH}

\author{
Jurnal Keperawatan dan Pemikiran \\ IImiah \\ Ferayanti, N (2017). Efektivitas \\ Terapi Rendam Kaki Air Hangat Dan \\ Relaksasi Nafas Dalam Terhadap \\ Tekanan Darah. Nurscope. Jurnal \\ Keperawatan dan Pemikiran IImiah.
}

3 (5). 38-45

\author{
Ni Made Ferayanti ${ }^{1}$, Rizky Erwanto ${ }^{2}$, Adi Sucipto ${ }^{3}$ \\ ${ }_{1,2,3}$ Universitas Respati Yogyakarta
}

\begin{abstract}
ABSTRAK
Pendahuluan: Prevalensi hipertensi di Indonesia sebesar 26,5\%. Sedangkan di Yogyakarta kasus hipertensi sebagai penyakit kardiovaskuler yang menyebabkan kematian tertinggi mencapai lebih dari $80 \%$, dan angka kejadian ini selalu meningkat setiap tahunnya. Dari hasil wawancara 56 responden dan melakukan pengukuran tekanan darah didapatkan 21 responden yang mengalami hipertensi. Untuk mengatasi hipertensi pada lansia peneliti mengkombinasikan dua terapi rendam kaki air hangat dan relaksasi nafas dalam. Tujuan dari penelitian ini untuk mengetahui efektivitas terapi rendam kaki air hangat dan relaksasi nafas terhadap tekanan darah pada lansia Di Rumah Pelayanan Lanjut Usia Budi Dharma Yogyakarta Metodologi : Penelitian ini merupakan jenis penelitian kuantitatif, metode yang digunakan quasi Experimental Desaign dengan rancangan pre and post test without control. Pengambilan sampel menggunakan total sampling. Teknik pengambilan data dengan cara observasi menggunakan sphygmomanometer digital. Analisa data dengan menggunakan Uji Paired simple t-test dengan nilai signifikan $\mathrm{p}<0,05$. Hasil : Hasil analisa data yang didapatkan tekanan darah responden setelah dibrikan terapi mengalami penurunan yang signifikan dengan nilai $\mathrm{p}$ sistolik dan $\mathrm{p}$ diastolik sebesar 0,000 . Dengan rata-rata perbedaan tekanan darah sistolik sebelum dan setelah diintervensi sebesar 22,71 $\mathrm{mmHg}$ dan diastolik 11,94 mmHg. Diskusi : Ada pengaruh yang signifikan terhadap penurunan tekanan darah sistolik dan diastolik sebelum dan sesudah diberikan terapi rendam kaki air hangat dan relaksasi nafas dalam pada lansia hipertensi di UPT Rumah pelayanan Lanjut Usia Budi Dharma Yogyakarta
\end{abstract}

Kata kunci : Lansia, Hipertensi, Terapi Rendam Kaki Air Hangat Dan Relaksasi Nafas Dalam

\title{
THE EFFECTIVENESS OF WARM WATER THERAPY AND DEEP BREATHING RELAXATION IN BLOOD PRESSURE
}

\section{ABSTRACT}

Introduction: Prevalence of hypertension in Indonesia is $26.5 \%$ WHILEhile in Yogyakarta cases of hypertension as a cardiovascular disease that causes the highest deaths reached more than $80 \%$, and the incidence rate is always increasing every year. From the results of interviews of 56 respondents and blood pressure measurement obtained 21 respondents who experienced hypertension. To overcome hypertension in elderly researchers combined two warm water foot soak therapy and deep breathing relaxation. The purpose of this research is to know the effectiveness of warm water foot soak therapy and deep breathing relaxation to blood pressure in elderly at Rumah Seni Seni Budi Dharma Yogyakarta. Methodology: This research is a quantitative research type, the method used quasi Experimental Desaign with pre and post test design control. Sampling using total sampling. Technique of collecting data by observation using digital sphygmomanometer. Data analysis using Paired simple t-test with significant value $p<0,05$. Result: The result of data analysis obtained by the respondent's blood pressure after the treatment therapies decreased significantly with pistol systolic and 
diastolic $p$ value of 0.000 . With an average systolic blood pressure difference before and after intervention of $22.71 \mathrm{mmHg}$ and diastolic $11.94 \mathrm{mmHg}$. Discussion: There is a significant effect on decreasing systolic and diastolic blood pressure before and after treatment of warm foot bath and deep breath relaxation in hypertensive elderly at UPT Budi Dharma Yogyakarta Senior High School

Keywords: Elderly, Hypertension, Soak Therapy Warm Water And deep breathing relaxation

Corresponding Author :

Adi Sucipto ${ }^{3}$, Universitas Respati Yogyakarta, Jln Tajem KM 1,5 Depok Maguwoharjo Sleman Yogyakarta. E-mail Penulis ${ }^{3}$ : adisuc2410@gmail.com

\section{PENDAHULUAN}

Lanjut usia merupakan suatu akibat yang terjadi dari proses menua, seseorang dikatakan lanjut usia belum dapat terjawab secara memuaskan namun para ahli dan organisasi kesehatan dunia member batasan atau klasifikasi yang hampir sama. Umur yang dijadikan patokan sebagai lanjut usia berbedabeda, umumnya berkisar antara 60-65 tahun ${ }^{1}$ (Maryam, 2008). Di Asia Tenggara termasuk Indonesia adalah salah satu Negara yang jumlah penduduk berusia 60 tahun ke atas telah mencapai di atas $7 \%$ dari keseluruhan penduduk. Peningkatan jumlah penduduk lansia ini disebabkan oleh peningkatan derajat kesehatan dan kesejahteraan penduduk yang akan berpengaruh pada peningkatan usia Harapan Hidup (UHH) di Indonesia ${ }^{2}$ (Riskesdes, 2013).

Berdasarkan survei penduduk antar sensus DIY masih menjadi propinsi di Indonesia yang memiliki propinsi lansia terbesar di Indonesia. Jumlah penduduk lansia di DIY mencapai 425.580 jiwa (12\%) dari total penduduknya yang berjumlah 3.343.651 jiwa ${ }^{3}$ (Badan Pusat Statistik, 2009). Dalam perkembangan lansia, penurunan fungsi tubuh akan banyak terjadi. Penurunan fungsi tubuh pada lansia diakibatkan karena proses penuaan. Proses penuaan merupakan proses yang mengakibatkan perubahan-perubahan meliputi fisik, fisiologis dan psikososial. Pada perubahan fisiologis terjadi penurunan sistem kekebalan tubuh dalam menghadapi gangguan dari dalam maupun luar tubuh. Salah satu gangguan kesehatan yang paling banyak dialami oleh lansia adalah pada sistem kardiovaskuler ${ }^{4}$ (Batubara, 2008).

Hipertensi didefinisikan sebagai tekanan darah sistolik lebih dari $140 \mathrm{mmHg}$ dan tekanan diastolik lebih dari $90 \mathrm{mmHg}$, berdasarkan dua kali pengukuran atau lebih ${ }^{5}$ (Smeltzer, 2013). Tekanan darah berubah dengan cepat bahkan pada kondisi kesehatan optimal. Perubahan tekanan darah bisa terjadi pada seseorang, hal ini dipengaruhi oleh usia, stress, etnik, jenis kelamin, variasi harian, obat-obatan, merokok, aktivitas dan berat badan. Kemungkinan seseorang mengalami hipertensi akan semakin tinggi saat usia semakin bertambah ${ }^{6}$ (Potter \& Perry, 2010). 
Hipertensi merupakan masalah besar, tidak hanya dinegara barat tapi juga di Indonesia. Hipertensi diderita oleh satu miliar orang diseluruh dunia dan diperkirakan tahun 2025 melonjak menjadi 1,5 miliar orang. Setiap tahun Hipertensi menyumbang kepada kematian hampir 9,4 juta orang akibat penyakit jantung dan stroke dan kejadian ini digabungkan, kedua penyakit ini merupakan penyebab kematian nomor satu didunia. ${ }^{7}$ (World Health Organizasion, 2013). Prevalensi hipertensi di Indonesia yang didapat melalui pengukuran pada umur $\geq 18$ tahun sebesar $25,8 \%$ dan yang didapat melalui kuisioner terdiagnosis oleh tenaga kesehatan sebesar 9,4\%, yang didiagnosis sedang minum obat sebesar 9,5\%. Jadi prevalensi hipertensi di Indonesia sebesar 26,5\% (Riskesdas,2013).

Berdasarkan laporan Sistem Terpadu Penyakit Tidak Menular Puskesmas (STP PTM) pada tahun 2014, didapatkan data dari 256.586 jumlah penduduk usia $>15$ tahun yang ada di Yogyakarta setelah dilakukan pengukuran tekanan darah sebanyak 40.363 (15,73\%) diketahui yang memiliki tekanan darah tinggi (hipertensi) sebanyak 7.464 (18,49\%). Prevalensi hipertensi di Indonesia pada golongan umur 50 tahun masih 10\% tetapi diatas usia 60 tahun angka tersebut terus meningkat mencapai 20$30 \%$. Sedangkan di Yogyakarta kasus hipertensi sebagai penyakit kardiovaskuler yang menyebabkan kematian tertinggi mencapai lebih dari $80 \%$, dan angka kejadian ini selalu meningkat setiap tahunnya (Depkes, 2009). Apabila hipertensi tidak ditangani atau dirawat akan menyebabkan kematian karena payah jantung, infark miokardium, stroke dan gagal ginjal ${ }^{8}$ (Price \& Wilson, 2006).

Secara garis besar pengobatan hipertensi dibagi menjadi dua yaitu pengobatan farmakologi dan non farmakologi. Pengobatan farmakologi banyak menyembuhkan hipertensi namun banyak memiliki efek samping seperti sakit kepala, pusing lemas dan mual terutama pada lansia yang sudah mengalami penurunan. Tindakan non farmakologi dapat dilakukan dengan cara berhenti merokok, menurunkan konsumsi alkohol berlebih, menurunkan asupan garam dan lemak, meningkatkan konsumsi buah dan sayur, penurunan berat badan berlebih, latihan fisik dan terapi alternatif komplementer "Hidrotherapy".

Hidrotherapy dapat menurunkan tekanan darah jika dilakukan secara rutin. Jenis hidrotherapy antara lain adalah mandi air hangat, mengompres, dan merendam kaki dengan air hangat. Secara ilmiah air hangat mempunyai dampak fisiologis bagi tubuh. Pertama berdampak pada pembuluh darah dimana hangatnya air membuat sirkulasi darah menjadi lancar (Lalage, 2015). Rendam air hangat bermanfaat untuk vasodilatasi aliran darah sehingga diharapkan dapat mengurangi tekanan darah ${ }^{9}$ (Ilkafah, 2016).

Pengobatan non farmakolagi salah satu tindakan yang dapat diberikan untuk menurunkan tekanan darah pada penderita hipertensi adalah tehnik relaksasi nafas dalam, dimana terapi relaksasi nafas dalam dapat dilakukan secara mandiri,relatif mudah dilakukan, tidak membutuhkan waktu lama 
untuk terapi, dan dapat mengurangi dampak buruk dari terapi farmakologis bagi penderita hipertensi ${ }^{10}$ (Hastuti, 2015).

Berdasarkan studi pendahuluan yang telah dilaksanakan di Panti Wredha Budhi Darma Yogyakarta pada tanggal 10 November 2016 di ruang perawat dengan cara wawancara pada perawat Panti, didapatkan jumlah lansia sebanyak 58 lansia dengan rincian jumlah lansia laki-laki 20 orang dan jumlah lansia perempuan sebanyak 38 orang. Hasil dari tekanan darah terakhir dari semua lansia didapatkan yang mengalami tekanan darah tinggi sebanyak 17 orang, dari hasil wawancara beberapa lansia juga menyatakan sering merasa pegal, sakit kepala dan tegang ditengkuk.

Tindakan yang sudah dilakukan yaitu dengan minum obat anti hipertensi. Berdasarkan latar belakang diatas peneliti tertarik untuk meneliti dengan mengkombinasikan dua terapi rendam kaki air hangat yang mana berdampak untuk vasodilatasi pembuluh darah serta relaksasi nafas dalam yang dapat mengurangi ketegangan otot-otot. Dengan judul penelitian yaitu "Efektivitas Terapi Rendam Kaki Air Hangat dan Relaksasi Nafas Dalam Terhadap Tekanan Darah pada Lansia.

\section{METODE}

Penelitian ini merupakan jenis penelitian kuantitatif, metode yang digunakan quasi Experimental Desaign dengan rancangan pre and post test without control. Tujuan Mengetahui efektivitas terapi rendam kaki air hangat dan relaksasi nafas terhadap tekanan darah pada lansia di Rumah Pelayanan Lanjut Usia Budi Dharma Yogyakarta. Penelitian ini dilakukan bulan April 2017 Di Rumah Pelayanan Lanjut Usia Budi Dharma Yogyakarta. Teknik pengambilan sampel menggunakan metode Total sampling. Teknik pengambilan data dengan lembar observasi menggunakan sphygmomanometer digital. Responden diberikan intervensi rendam kaki air hangat selama 15 menit dan berbarengan dengan terapi relaksasi nafas dalam selama 15 menit. Analisa data dengan menggunakan Uji Paired simple t-test dengan nilai signifikan $p<0,05$. 
HASIL

Tabel 1 Distribusi frekuensi responden intervensi menurut jenis kelamin, konsumsi obat dan usia di rumah Pelayanan Lanjut Usia Budi Dharma Yogyakarta, bulan April 2017 (n=17)

\begin{tabular}{|c|c|c|}
\hline \multirow[t]{2}{*}{ Variabel } & \multicolumn{2}{|c|}{ Intervensi } \\
\hline & Frekuensi (f) & Persentase (\%) \\
\hline \multicolumn{3}{|l|}{ Usia(tahun) } \\
\hline Elderly 60-74 & 11 & 64,7 \\
\hline Old $\quad 75-90$ & 6 & 35,3 \\
\hline \multicolumn{3}{|l|}{ Jenis Kelamin } \\
\hline Laki-laki & 7 & 41,2 \\
\hline Perempuan & 10 & 58,8 \\
\hline \multicolumn{3}{|l|}{ Konsumsi Obat } \\
\hline Ya & 4 & 23,5 \\
\hline Tidak & 13 & 76,5 \\
\hline Total & 17 & 100,0 \\
\hline
\end{tabular}

Tabel 2 Tekanan Darah Sistolik Dan Diastolik Sebelum Pemeberian Terapi Rendam Kaki Air Hangat Dan Relaksasi Nafas Dalam Di Rumah Pelayanan Lanjut Usia Budi Dharma Yogyakarta, bulan April 2017.

\begin{tabular}{lrrr}
\hline \multicolumn{1}{c}{ TD (mmHg) } & Mean & Std. deviation & Std. Error \\
\hline Pre & & & \\
Sistolik & 155,94 & 10,74 & 2,60 \\
Diastolik & 89,52 & 5,11 & 1,24 \\
\hline
\end{tabular}

Tabel 3 Tekanan Darah Sistolik Dan Diastolik Setelah Pemeberian Terapi Rendam Kaki Air Hangat Dan Relaksasi Nafas Dalam Di Rumah Pelayanan Lanjut Usia Budi Dharma Yogyakarta, bulan April 2017.

\begin{tabular}{lrrr}
\hline TD (mmHg) & Mean & Std. Deviation & \multicolumn{1}{c}{ Std. Error } \\
\hline Post 1 & & & \\
Sistolik & 139,41 & 7,15 & 1,73 \\
Diastolik & 83,00 & 3,10 & 0,75 \\
\hline Post 2 & & & \\
Sistolik & 133,23 & 5,43 & 1,31 \\
Diastolik & 77,58 & 4,06 & 0,98 \\
\hline
\end{tabular}

Tabel 4 Tekanan Darah Sistolik dan Diastolik Sebelum dan setelah intervensi di Rumah Pelayanan Lanjut Usia Budi Dharma Yogyakarta, bulan April 2017.

\begin{tabular}{lrrrr}
\hline TD (mmHg) & Mean & Std.D & Selisih & p-value \\
\hline Pre & & & & \\
Sistolik & 155,94 & 10,74 & 16,53 & 0,000 \\
Diastolik & 89,52 & 5,11 & 6,52 & 0,000 \\
\hline Post 1 & & & & \\
Sistolik & 139,41 & 7,15 & 16,18 & 0,000 \\
Diastolik & 83,00 & 3,10 & 5,42 & 0,000 \\
\hline
\end{tabular}




\begin{tabular}{lrrrr}
\hline Post 2 & & & & \\
Sistolik & 133,23 & 5,43 & 22,71 & 0,000 \\
Diastolik & 77,58 & 4,06 & 11,94 & 0,000 \\
\hline
\end{tabular}

\footnotetext{
*) : Uji Paired-Samples T Test

*) : Uji Repeated ANOVA
}

\section{PEMBAHASAN}

Total 17 orang responden, sebagian besar responden berusia 60-74 tahun yakni sebanyak 11 orang $(64,7 \%)$, sebagian besar responden berjenis kelamin perempuan yakni 10 orang $(58,8 \%)$, dan sebagian besar responden yang tidak mengonsumsi obat yakni 13 orang (76,5\%). Rata-rata tekanan darah sistolik pada lansia di Rumah Pelayanan Lanjut Usia Budi Dharma sebelum diintervensi adalah sebesar 155,94 mmHg dan rata-rata tekanan darah diastolik responden adalah sebesar 89,52 mmHg. Hal ini didukung oleh penelitian Santoso (2015) yang menyatakan dari 16 responden $(56,25 \%)$ responden mengalami hipertensi derajat 1 . Menurut Smelzer (2013) seseorang yang mengalami hipertensi dengan tekanan darah sistolik 140-159 mmHg termasuk golongan hipertensi derajat 1.

Hasil penelitian menunjukkan bahwa rata-rata tekanan darah sistolik pada lansia di Rumah Pelayanan Lanjut Usia Budi Dharma setelah diintervensi adalah sebesar 133,23 mmHg dan rata-rata tekanan darah diastolik responden adalah sebesar $77,58 \mathrm{mmHg}$. Hasil menunjukkan bahwa terjadi penurunan tekanan darah sistolik dan diastolik pada lansia di Rumah Pelayanan Lanjut Usia Budi Dharma Yogyakarta setelah diberikan terapi rendam kaki air hangat dan relaksasi nafas dalam selama 2 minggu dengan penurunan rata-rata sitolik sebesar 22,71 $\mathrm{mmHg}$ dan diastolik sebesar 5,45 mmHg. Hasil uji statistik sebelum dilakukan intervensi yakni nilai $P$-value tekanan darah sistolik sebesar 0,000 $(0,000<0,05)$ dan $p$-value tekanan darah diastolik sebesar $0,000(0,000<0,05)$. Setelah dilakukan terapi selama 1 minggu nilai $P$-value tekanan darah sistolik sebesar $0,000(0,000<0,05)$ dan tekanan darah $p$-value tekanan darah diastolik sebesar 0,001 $(0,000<0,05)$. Kemudian setelah 2 minggu nilai $P$-value tekanan darah sistolik sebesar $0,000(0,000<0,05)$ dan $p$-value tekanan darah diastolik sebesar $0,000(0,000<0,05)$. Maka dapat disimpulkan ada pengaruh yang signifikan terhadap penurunan tekanan darah sistolik maupun diastolik sebelum dan setelah 2 minggu diintervensi dengan nilai $P$-value $<0,05$.

Hal ini sejalan dengan penelitian (Umi \& Priyanto 2014) pada penelitiannya menyatakan penurunan rata-rata tekanan darah sistolik sebesar 19,1 mmHg dan diastolik sebesar 11,9 mmHg. Hal ini juga didukung oleh penelitian Putri, ddk (2015) yang menyatakan bahwa penurunan rata-rata tekanan 
darah sistolik setelah diberikan terapi rendam menggunakan air hangat dan senam lansia adalah $12,73 \mathrm{mmHg}$.

Penurunan tekanan darah setiap individu berbeda-beda dikarenakan setiap individu memiliki respon tubuh yang berbeda setelah diberikan terapi rendam kaki air hangat dan relaksasi nafas dalam. Hasil penelitian ini didukung dengan penelitian (Yusrizal, 2012) yang menyatakan bahwa relaksasi nafas dalam dapat menurunkan tekanan darah pada pasien hipertensi yang dilakkan selama 1 minggu. Dari hasil tekanan darah setelah dilakukan terapi menunjukkan bahwa tekanan darah responden tergolong dalam Prahipertensi. Dalam teori (Smelzer, 2013) menyatakan seseorang yang mengalamai tekanan darah sistolik 120-139 mmHg termasuk Prahipertensi.

Rendam air hangat bermanfaat untuk melancarkan aliran darah sehingga diharapkan dapat mengurangi tekanan darah (Ilkafah, 2016). Rendam air hangat juga berdampak pada pembuluh darah dimana hangatnya air membuat sirkulasi darah menjadi lancar dan melebarkan pembuluh darah (Lalage, 2015). Relaksasi merupakan kebebasan mental dan fisik dari ketegangan dan stress. (Potter \& Perry, 2010). Manfaat dari relaksasi nafas dalam adalah menimbulkan rasa tenang dan nyaman, mengurangi rasa nyeri, melemaskan otot untuk menurunkan ketegangan, kejenuhan, dan mengurangi stress (Setyoadi \& Kushariyadi 2011)

\section{SIMPULAN DAN SARAN}

\section{Simpulan}

Sebelum diberikan terapi rendam kaki air hangat dan relaksasi nafas dalam rata-rata tekanan darah sistolik sebesar 155,94 mmHg dan diastolik $83,00 \mathrm{mmHg}$. Setelah diberikan terapi rendam kaki air hagat dan relaksasi nafas rata-rata tekanan darah sistolik sebesar $133,23 \mathrm{mmHg}$ dan diastolik 77,58 $\mathrm{mmHg}$. Terdapat penurunan yang signifikan terhadap tekanan darah sistolik maupun diastolik respondan sebelum dan setelah 2 minggu dilakukan terapi rendam kaki air hangat dan relaksasi nafas dalam dengan rata-rata perbedaan sistolik sebesar 22,71 $\mathrm{mmHg}$ dan diastolik 11,94 $\mathrm{mmHg}$.

\section{Saran}

Berdasarkan hasil penelitian lansia dapat mengikuti jadwal terapi rendam kaki air hangat dan relaksasi nafas dalam secara rutin sesuai jadwal yang sudah ditetapkan dan bisa melakukan dengan baik secara mandiri. Perawat dapat menggunakan terapi rendam kaki air hangat dan relaksasi nafas dalam sebagai salah satu intervensi keperawatan untuk mengatasi tekanan darah pada lansia hipertensi. Pengelola UPT dapat mengatur jadwal untuk melakukan terapi rendam kaki air hangat dan relaksasi nafas dalam sebagai kegiatan yang wajib diikuti oleh seluruh lansia. Hasil penelitian ini 
sebagai dokumentasi perpustakaan dan menjadi acuan bagi peneliti selanjutnya. Dan peneliti selanjutnya dapat mengembangkan terapi komplementer keperawatan yang lainnya untuk mengatasi masalah hipertensi pada lansia.

\section{KEPUSTAKAAN}

Maryam, R. Siti, et al. (2008). Mengenal Usia Lanjut dan Perawatannya.Jakarta : Salemba Medika.

Riskesdas.(2013). Riset Kesehatan Dasar.Jakarta:Kemenkes RI

BPS( 2009). Lansia di Indonesia. http://www.lansia.go.id. Diakses 29 november 2016

Baharuddin. 2013. Perbandingan Efektivitas Dan Efek Samping Obat Antihipertensi Terhadap Penurunan Tekanan Darah Puskesmas Bendosari Kabupaten Sukoharjo. Jurnal Terpadu IImu Kesehatan, 4(2).

Smeltzer. (2013). Keperawatan Medikal Bedah. Jakarta:EGC

Potter \& Perry. (2010). Buku Ajar Fundamental Keperawatan. Jakarta:EGC

WHO. (2013). A Global Brief On HypertensionSilent Killer, Global Public Health Crisis.http://www.who.int/cardiovascular_diseases/publications/global_brief_hypertension/e n/. Diakses tanggal 29 oktober 2016

Price, A. Sylvia, Lorraine Mc. Carty Wilson, (2006), Patofisiologi : Konsep Klinis Proses-proses Penyakit, Edisi 6, (terjemahan), Peter Anugrah, EGC, Jakarta.

Ilkafah, I. (2016). Perbedaan Penurunan Tekanan Darah Lansia Dengan Obat Anti Hipertensi Dan Terapi Rendam Air Hangat Di Wilayah Kerja Puskesmas Antara Tamalanrea Makassar. Pharmacon, 5(2).

Hastuti, R. T., \& Insiyah, I. (2015). Penurunan Tekanan Darah Dengan Menggunakan Tehnik Nafas Dalam (Deep Breathing) Pada Pasien Hipertensi Di Puskesmas Bendosari Kabupaten Sukoharjo. Jurnal Terpadu IImu Kesehatan, 4(2).

Destia, D.,Umi, A., Priyanto. (2014). Perbedaan Tekanan Darah Sebelum Dan Sesudah Dilakukan Hidroterapi Rendam Hangat Pada Penderita Hipertensi Di Desa Kebondalem Kecamatan Jambu Kabupaten Semarang. Jurnal Stikes Ngudi Waluyo Ungaran 2014. 4-9.

Putri, Ddk (2015). Efektifitas Terapi Menggunakan Air Hangat Dan Senam Lansia Terhadap Tekanan Darah Di Unir Rehabilitas Sosial (Uresos) Pucang Gading Unit Semarang II. Diakses Tanggal 10 Mei 2017 